\title{
Contributors
}

John Marinan IV is a PhD candidate at Northern Illinois University, studying rhetoric, specifically in the areas of autism and disability. He is interested in how historical documents create dialogues between key players, and how those interactions can be seen ideologically.

C. W. R. D. Moseley is a Fellow and former Senior Tutor of Hughes Hall, Cambridge, and Director of Studies in English. He is Affiliated Lecturer in the Faculty of English, University of Cambridge and has taught Classics and English Literature in the University for many years. He is General Editor (Literature Insights) of the unique and innovative academic e-book project Humanities-Ebooks.co.uk

The author of an extensive list of academic and other publications, he has lectured at universities, schools and societies in many countries around the world on topics ranging from Shakespeare, the history of travel literature, the Norse diaspora, and Medieval religious art to his own travels in the Arctic. Recent published essays range from Elizabethan painting, and Jacobean drama,to nineteenth century printing technology and the topographical drawings of Alfred Wainwright.

Svenn-Arve Myklebost (managing editor) is currently an associate professor at Volda University College, Norway, where he teaches English literature and culture. Among his publications are articles and book chapters on Shakespeare, Laurence Sterne, adaptation/configuration, manga and graphic novels, published on Cambridge UP, Universitetsforlaget, Ashgate and others. He has taught in Volda, at the University of Bergen and at the Cambridge Shakespeare Summer School. Myklebost is a member of the Bergen Shakespeare and Drama Network (BSDN) and a founding member of the Nordic Network for Comics Research (NNCORE).

Sandra Pietrini is Professor of Theatre History at the University of Trento. She directs the work in progress Arianna, a database of images and texts related to classics, whose "Shakespeareana" section (http://laboratorioteatrale.lett.unitn.it/progetto-arianna/shakespeariana.html) contains about 10.000 items. She has published articles in various Italian and international publication. She has been editor and co-author of the Italian edition of Living Theatre by E. Wilson and A. Goldfarb (Storia del teatro, McGrawHill 2010). Among her monographies are, Spettacoli e immaginario teatrale nel Medioevo (Bulzoni 2001), Fuori scena. Il teatro dietro le quinte nell'Ottocento (Bulzoni 2004), Il mondo del teatro nel cinema (Bulzoni 2007), L'arte dell'attore dal Romanticismo a Brecht (Laterza 2009) and I giullari nell'immaginario medievale (Bulzoni 2011). 
Anne Sophie Refskou holds a BA and MA in English and Comparative Literature from University of East Anglia, and is currently a PhD fellow at Aarhus University, Denmark. Her main research area is early modern English drama and conceptions of compassion and performance. She also works theoretically and practically with body language and physical interaction in performing early modern drama - particularly Shakespeare - and has been a frequent speaker and workshop leader on this subject in the UK, Brazil, and Denmark. She has been academic visitor at The Shakespeare Institute, Stratford-upon-Avon, and published in New Theatre Quarterly and Cultural History.

Laura Søvsø Thomasen holds a PhD in comparative literature from Aarhus University, Denmark. Her main research area is the interrelations between literature, visual culture and science, primarily during the early modern period. Her PhD dissertation dealt with the visual and literary strategies of science in the early modern period. Thomasen's publications include articles on literature and gambling, the reception of Charles Darwin in Denmark, the microscopic studies of Robert Hooke and the relationship between Danish literature and science.

Matthew Wagner is Senior Lecturer in Theatre and Programme Director for Theatre Studies at the University of Surrey. His research is focused primarily on Shakespearean dramaturgy and stage praxis, but it reaches also into the 20th and 21st centuries, particularly in respect to theatrical temporality, the theatre of Beckett and his contemporaries, and questions of embodiment and spatiality in theatre and performance. More broadly, nearly all his research activity is underpinned by a fascination with the relationship between phenomenology and theatre. Current projects include co-convening a series of symposia and workshops on the nature of the door in performance, co-editing a collection of essays on phenomenology and performance, and the development of a manuscript on the phenomenology of Shakespeare.

Ayşegül Yayla has a Research Master's degree at the University of Leiden, the Netherlands, in the field of Literary Studies. She majored in Cultural Studies and minored in Art Theory and Criticism at Sabanci University in Istanbul, Turkey. Yayla is experienced in qualitative research, data analysis and concept development. She is interested in Gender Studies and its relationship with performance through psychoanalytical and structualist approaches to sexuality in art and media. 


\section{Call for contributions}

As always, we will accept research articles that present original material on early modern topics within the fields of literature, history, art history, philosophy, music and language - or cross-disciplinary combinations thereof. We also accept "notes," i.e. short articles that argue or observe one specific point, as well as survey articles that present a topic and extant literature pertaining to it. Lastly, we will now also accept book reviews on scholarship related to the early modern period.

Excluding the bibliography, a research article or a survey article should be between 3.000 and 10.000 words. Notes and book reviews should be between 1.000 and 2.000 words.

There are also two non-peer reviewed sections of the journal for which we welcome contributions. The first is the en face exposé: two pages, one containing a poem, an image, an extract from a play or a musical score or a religious tract, or something else - and the other containing a description of the object in question. This is a useful channel for disseminating information about curiosities, underappreciated works, or things that are just plain amusing, in a less formal setting than that of the note or article. The other section is for opinion pieces, where one may take a step back and address, for example, the status of early modern studies in today's financial climate, the teaching of early modern topics, issues of cross-disciplinary research, early modern studies and digital humanities or any other relevant topic.

Please consult the author guidelines at the EMCO web site for more information about how to submit: http://journal.uia.no/index.php/EMCO

Note that one has to register as a contributor before submitting any kind of piece. In case of technical issues, please contact the managing editor: svenn-arve.myklebost@hivolda.no 